\title{
MULTIMEDIA INTERAKTIF MATERI TEKNIK BATIK JUMPUTAN PEMBELAJARAN SENI BUDAYA DAN KETERAMPILAN SDN 50 DAN 53 KAMPUNG JAMBAK PADANG
}

\author{
San Ahdi ${ }^{1 *}$, Eliya Pebriyeni ${ }^{*}$, Erwin $^{3 *}$, Ariusmedi $^{4^{*}}$ \\ Jurusan Seni Rupa Fakultas Bahasa dan Seni \\ Universitas Negeri Padang \\ Jl.Prof. Dr. Hamka, Air Tawar Padang, Kel. Air Tawar Barat, Kec. Padang Utara, Kota Padang, Kode Pos 25171 \\ Sumatera Barat. Indonesia \\ Email:san_ahdi@fbs.unp.ac.id,elyafebriyeni@fbs.unp.ac.id,erwin.senirupa@fbs.unp.ac.id, \\ ariusmedi3@gmail.com
}

\begin{abstract}
Abstrak
Materi pembelajaran seni rupa sering kali dilewati guru, atau tidak diajarkan kepada murid-murid. Begitu juga pada materi batik jumputan ini guru berang gapan dalamproses pembuatan batik ini, motif yang digunakan menuntut kemampuan guru untuk mengggambar, padahal tidak. Batik jumputan ini dalam proses pengerjaannya sangatlah mudah tidak menuntut kemampuan guru untuk pandai menggambar. Batikjumputan ini hanya menggunakan leknik ikat celup pada sebidang kain. Kain yang sudah diikat sesuai dengan keinginan masing-masing lalu dicelupkan kedalam larutan warna batik. Kemudian guru-guru di dalam menjelaskan materi kebanyakan menggunakan metode ceramah. Sehingga siswa menjadi tidak tertarik untuk mempelajari materi yang diberikan. Oleh sebab itu guru dalammenjelas kan materi perlu dibuatkan suatu med ia yang menarik deng an tampilan visual y ang dapat menarik sis wa, seperti dibuatkan multimedia interaktif presentasinya. Masalah y ang dis elesaikan dilihat dari tiga as pek kegiatan pembelajaran, yaitu: (1) aspek penguasaan materi pembelajaran seni budaya dan keterampilan,(2) Aspek penerapan materipembelajaran seni budaya dan keterampilan, (3) Aspek pembuatan multimedia interaktif presentasi materipembelajaran seni budaya dan keterampilan. Metode pendekatan y ang digunakan: Rancang bangun media dan model pelatihan, penyuluhan, pelatihan atau workshop, praktik pembelajaran. Luaran yang dihasilkan adalah sekitar $80 \%$ materi tentang batik jumputan dikuasai oleh guru, terlihat dari karya yang sudah dihasilkan yaitu karya batik jumputan berupa alas meja. Dan telah terjadi peningkatan pemahaman guru-guru dalam menguasai materi multimedia interaktif dalam pembuatan video pembelajaran materibatik ju mputan sekitar $80 \%$ materi pelatihan dikuasai.
\end{abstract}

Kata Kunci: multimedia interaktif, batik jumputan.

\begin{abstract}
The teacher often skipsart learning material, or isn't taught to students. Likewise in this jumputan batik material the teacher thinks that in the process of making this batik, the motive used demands the teacher's ability to draw pictures, but it is not. This jumputan batik in the process ofmaking it very easy does not require the ability of the teacher to be good at drawing. This jumputan batik only uses the tiedye technique on a piece of cloth. The cloth that has been tied according to their wishes is then dipped in a batik color solution. Then the teachers in explaining the material mostly used the lecture method. So that students are not interested in studying the material provided. Therefore the teacherin explaining the material needs to make an attractive media with a visual appearance that can attractstudents, such as making interactive multimedia presentations. The problems that are resolved are seen from three aspects oflearning activities, namely: (1) aspects ofmastery of art and culture learning materials and skills, (2) Aspects of application of learning materials for arts and culture and skills, (3) Aspects of making interactive multimedia presentations on learning materials for arts and culture and skills. The approach method used: Media design and training models, counseling, training or workshops, learning practices. The output produced is that about $80 \%$ of the material about jumputan batik is controlled by the teacher, it can be seen from the work that has been produced, namely the jump utan batik work in the form of table mats. And there has been an increase in the understanding of teachers in mastering interactive multimedia material in making learning videos of batik jumputan material, about $80 \%$ of the training material is mastered.
\end{abstract}

Keywords: interactive multimedia, batik's jumputan. 


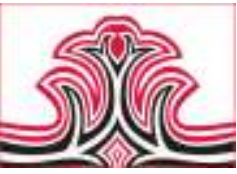

\section{PENDAHULUAN}

Salah satu metode pengajaran seni rupa yang paling sering dilakukan dalam pendidikan formal adalah metode mencontoh (copy the master). Guru biasanya memberikan contoh gambar dipapan tulis untuk ditiu oleh para siswa. Tentu saja hasil yang bisa dilihat adalah para siswa sebagian besar atau setidaknya sebagian bisa membuat gambar sesuai dengan yang dicontohkan gurunya. Kelihatannyaini adalah sebuah keberhasilan, padahal sesungguhnya ini adalah sebuah kegagalan.

Pembelajaran seni rupa di sekolah mengembangkan kemampuan sis wa dalam berkarya seni yang bersifat visual dan rabaan. Pembelajaran seni rupa memberikan kemampuan bagi siswa untuk memahami dan memperoleh kepuasan dalam menanggapi karya seni rupa ciptaan siswa sendii maupun karya seni rupa ciptaan orang lain. Melalui pengalaman berkarya, siswa memperoleh pemahaman tentang berbagai penggunaan media, baik media untuk seni rupa d wimatra maupun seni rupa trimatra. Dalam berkarya seni rupa, siswa belajar menggunakan berbagai teknik tradisional dan modem untuk mengeks ploitasi sifat-sifat dan potensi estetik media. Melalui seni rupa, siswa belajar berkomunikasi melalui gambar dan bentuk, serta mengembangkan rasa kebanggaan dalam menciptakan ungkapan pikiran dan perasaannya.

Bidang seni rupa tidak hanya menggambar saja, namun ada berbagai macam jenis keterampilan yang bisa menarik perhatian siswa. Salah satu jenis keterampilan yang bisa dikerjakan oleh sis wa adalah membatik. Membatik adalah suatu jenis keterampilan yang harus dilestarikan di lingkungan sekolah. Di sekolah dasar ada materi yang tercantum dalam kurikulum yang luput oleh gurunya, yaitu membatik ini. Di sekolah mitra SDN 50 dan 53 kampung jambak, materi batik ada didalam kurikulum khusus materi batik jumputan, namun materi ini tidak diajarkan oleh guru karena keterbatasan kemampuan guru untuk mengaplikasikannya ke siswa. Guru tidak tahu bagaimana teknik pengerjaan daribatik jumputan ini. Materi batikjumputan iniada pada mata pelajaran seni budaya dan keterampilan, sehingga materi batik jumputan ini selalu diganti dengan prakarya lain, yang sifat itu-itu saja dari masa ke masa dan materi yang diberikan atau jenis tugas yang diberikan tidak bervariasi.

Khusus untuk materi pembelajaran seni budaya dan keterampilan, sebahagian besar materi pembelajaran praktikum memerlukan kegiatan/kemampuan
Gorga : Jurnal Seni Rupa Volume 09 Nomor 02 Juli-Desember 2020 p-ISSN: 2301-5942 | e-ISSN: 2580-2380

menggambar. Dengan demikian, maka guru seni rupa di SD harus menguasai materi/bahan pembelajaran menggambar. Secara formal, kemampuan guru SDN Mitra dalam menguasai bahan/materi pembelajaran seni rupa sangat kurang, karena mereka menganggap untuk menguasai materi menggambar tersebut perlu bakat. Apalagi akibat kemajuan Ilmu Pengetahuan dan Teknologi (IPTEKS), mengakibatkan perlunya peningkatan kemampuan guru. Bahkan materi pembelajaran seni rupa sering kali dilewati guru, atau tidak diajarkan kepada murid-murid. Begitu juga pada materi batik jumputan ini guru beranggapan dalam proses pembuatan batik ini, motif yang digunakan menuntut kemampuan guru untuk mengggambar, padahal tidak. Batik jumputan ini dalam proses pengerjaannya sangatlah mudah tidak menuntut kemampuan guru untuk pandai menggambar. Batik jumputan ini hanya menggunakan teknik ikat celup pada sebidang kain. Kain yang sudah diikat sesuai dengan keinginan masing-masing lalu dicelupkan kedalam larutan warna batik.

Berdasarkan uraian di atas dapat ditarik kesimpulan bahwa dalam pembelajaran Seni Budaya dan Keterampilan sangat penting selain itu kompetensi guru juga sangat dituntut untuk meningkatkan kreativitas murid. Bahkan latar belakang pendidikan guru juga sangat menentukan proses belajar mengajar yang efektif. Salah satu upaya untuk meningkatkan kompetensi guru adalah guru harus bis a memilih bahan yang cocok, yang ada di lingkungan sekitar untuk dijadikan bahan dalampembuatan prakarya. Guru juga harus mampu meningkatkan pemahamannya tentang pembelajaran seni budaya dan keterampilan. Pada pembelajaran seni budaya dan keterampilan di SDN mitra, ada materi tentang seni rupanya yang tidak bisa diberikan oleh guru kepada murid, karena guru tidak mengetahui tentang materi tersebut. Jadi tingkat pemahaman/penguasaan dan penerapan materi pembelajarannya sangat kurang sekali. Contohnya, ada didalam pembelajaran seni budaya dan keterampilan tentang keterampilan membatik, tetapi karena guru tidak memahami konsep, materi, teknik, maupun proses membatik, sehingg a materi ini tidak diajarkanke murid.

\section{KAJIAN TEORI}

Landasan teori merupakan suatu perangkat untuk melakukan penelitian dalammenyelidiki mas alah yang diteliti, menyusun bahan yang diperoleh, analisis sumber dan analisis hasil temuan di lapangan. Sehubungan dengan hal ini, Lexy J. Moleong dalam Metodologi Penelitian Kualitatif, menjelaskan bahwa seorang penelitiyang mengadakan penelitian kualitatif 
bias anya berorientasi pada teori yang sudah ada. Pada penelitian kualitatif, teori dibatasi pada pengertian, suatu pernyataan sistematis yang berkaitan dengan seperangkat proposisi yang berasal dari data dan diuji kembali secara empiris (Moleong, 2005: 14).

Menurut Wardoyo (2018) Tie-dye merupakan salah satu produk budaya dan tradisi dalampembuatan motif di atas kain yang dikenal cukup luas tidak hanya di Indonesia saja, melainkan juga di hampir selunuh penjuru dunia. Istilah tie-dye apabila diterjemahkan secara sederhana sebagai leksikon ke dalam bahasa Indonesia artinya adalah 'ikat celup'. Tie-dye mengandung pengertian bahwa dalam proses pembuatan motif di atas kain dipergunakan is tilah ikat sebagai proses merintangi atau menahan warna, sedangkan istilah celup diartikan sebagai proses pemberian warna. Menjumput berarti memungut atau mengambil dengan semua ujung jari tangan. Cara pembuatan kain jumputan sangat sederhanadan mudah dilakukan karena tidak menggunakan lilin dan canting (Rini Ningsih dalam Astuti, 2014).

\section{METODE PENELITIAN}

Pemecahan masalah dilakukan dengan menerapkan IPTEKS sesuai dengan permasalahan mitra dengan menggunakan metode pendekatan; 1). Rancangbangun media dan model pelatihan yang akan dijadikan sebagai panduan bahan latihan oleh Tim Pelaksana dan guru SDN 50 dan 53 Kampung Jambak sebagai peserta, 2). Penyuluhan yang dilakukan dengan metode ceramah dan tanya jawab dalammenyajikan materi untuk ketiga aspek permas alahan, 3). Pelatihan atau works hop yang dilakukan oleh guru SDN 50 dan 53 Kampung Jambak sebagai peserta pengabdian masyarakat, pelathan dilakukan dengan bimbingan dari instruktur, dan 3). Penerapan merupakan praktik pembelajaran dengan materibatikjumputan sesuai dengan materi pengabdian kepada masyarakat ini yang dilakukan guru SDN 50 dan 53 Kampung Jambak dalamkelasnya sendiri. Baik itu penerapan dalam pembuatan karya maupun pembuatan multimedia interaktif persentasi dalam penyampaian materi batik jumputan ke siswa.

\section{HASIL DAN PEMBAHASAN}

\section{Hasil}

Hasil yang dicapai sesuai dengan langkahlangkah kegiatan dan spesifikasi target luaran, yaitu:

1. Persiapan Administrasi dan Rekrutmen Peserta Ada tiga jenis kegiatan yang dilaks anakan pada langkah persiapan ini, yaitu: (1) Penetapan jadwal konkrit dan tempat pelaksanaan kegiatan, (2) Koordinasi dan pengurusan izin, dan (3) Rekrutmen dan seleksi peserta.
Gorga : Jurnal Seni Rupa

Volume 09 Nomor 02 Juli-Desember 2020

p-ISSN: 2301-5942 | e-ISSN: 2580-2380

Penetapan jadwal konkrit merupakan kegiatan penentuan/penetapan jadwal pelaks anaan kegiatan di lapangan. Tanggal 24 Agustus 2020 tim mengkonfirmasikan tentang penetapan tanggal pelaksanaan kegiatan dengan Kepala SDN 50 Kampung Jambak dan tanggal 25 Agustus 2020 dengan Kepala SDN 53 Kampung Jambak Padang. Penetapan tanggal dilakukan dengan cara video call whatshap. Hasil pertemuan tersebut adalah didapatkan kesepakatan antara timPelaksana dengan Kepala SDN 50 dan SDN 53 Kampung Jambak Padang. Kesepakatan tersebut adalah: kegiatan dilaksanakan dari tanggal 3 september sampai dengan 9 september 2020, kecuali hari minggu tanggal 6 september 2020 dan tempat pelaksanaan kegiatan adalah di SDN 53 Kampung Jambak Padang.

Koordinasi dan pengurusan izin dilakukan oleh Tim Pelaksana dengan Ketua LP2M UNP Padang. Hasil yang didapatkan adalah suratizin pelaks anaan kegiatan yang dikeluarkan LP2M UNP Padang dan ditujukan kepada: (1) Kepala UPTD Pendidikan KecamatanKoto Tangah, (2) Kepala SDN 50 Kampung Jambak, dan(3) SDN 53 Kampung Jambak Padang.

Rekrutmen dan seleksi peserta yang dilakukan atas kerjasama Tim Pelaksana dengan Kepala SDN 50 dan SDN 53 Kampung Jambak Kecamatan Koto Tangah Padang. Hasilnya didapat dari hasil seleksi sebanyak 10 orang peserta dan ditambah dengan 2 orang kepala sekolah yang ikut dalam pelatihan tersebut. Hasil seleksi dilakukan oleh Kepala SDN 50 dan SDN 53 Kampung Jambak Kecamatan Koto Tangah Padang.

Pelaks anakan Kegiatan, dengan jenis kegiatan dibagi atas: persiapan, pelaksanaan pelatihan/workshop, penerapan, dan evaluasi keberhasilan.

1) Persiapan pelatihan berupa:

Rancang bangun media dan model pelatihan yang akan dijadikan sebagai pegangan bagi tim pelaksana dan peserta dalam mengikuti PKM ini. Hasil yang didapatkan adalah: (1) Media pembelajaran berupa power point, dan (2) Model prakarya dengan teknik batik jumputan

Dihasilkan beberapa teknik ikatan atau lipatan yang digunakan dalam pembuatan batik jumputan untuk menghasilkan motifmotif bervariasi yang nantinya akan digunakan guru-guru dalam proses praktikum pembelajaran SeniBudaya dan Keterampilan/Prakarya dikelas. Dihasilkan bahan dan alat praktikum yang akan digunakan selama kegiatan PKM ini dilaksanakan. Pelaks anaan pelatihan/workshop dengan 


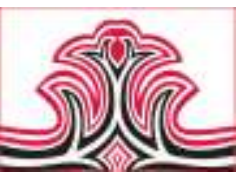

jenis kegiatan berupa: Distribusi bahan dan alat kepada peserta PKM. Setiap peserta mendapatkan: bahan pelatihan berupa printout powerpoint, peralatan administrasi untuk keperluan pencatatan, bahan dan alat praktikum untuk mengaplikasikan pengetahuan yang dimiliki dalam bentuk karya. Penyajian maten dalam bentuk penyuluhan untuk meningkatkan pemahaman peserta pelatihan terhadap materi PKM ini.

Setelah pembukaan, diberikan pretest tentang kemampuan awal peserta menguasai materi tentang batik jumputan sebagai bahan praktikum pada pembelajaran seni budaya dan prakarya. Kemudian sejauhmana kemampuan guru didalammembuat video pembelajaran yang menarik untuk dijadikan media bagi guru dalam menyampaikan materi batik jumputan ini. Selanjutnya dilaksanakan kegiatan, dan pada akhir pelaksanaan kegiatan kembali diukur kemampuan peserta.

Guru SDN 50 dan SDN 53 Kampung Jambak belum dapat memahami pengertian, konsep, bahan, dan proses pembuatan karya seni rupa dan keterampilan dengan menggunakan Teknik batik jumputan sebagai bahan pembuatan karya praktikum. Padahal dalamkurikulum ditingkat SD ada materi yang memang mempelajari tentang batik jumputan ini, namun pengetahuan guru dalam menguasai materi ini sangat terbatas, sehingga materibatikjumputan tidak diajarkan oleh guru. Dilihat dari hasil pengukuran kemampuan awal peserta, didapatkan sekitar $40 \%$ materi pengertian, konsep, bahan, dan proses pembuatan karya seni rupa dan keterampilan dengan menggunakan teknik batik jumputan dikuasai oleh guru sebagai bahan pembuatan karya praktikum. Pada akhir kegiatan, dilakukan lagi pengukuran sekitar $80 \%$ materi pengertian, konsep, dan proses pembuatan karya seni rupa dan keterampilan dengan menggunakan teknik batik jumputan sebagai bahan pembuatan karya praktikum sudah dikuasai oleh Guru SDN Mitra. Tingkat persentese ini sudah melebihi target penguasaan yang ditetapkan sebanyak $75 \%$.

Selanjutnya diberikan materi tentang: (1) Proses pembuatan multimedia interaktif dalam pembuatan media pembelajaran tentang teknik batik jumputan, yang nantinya akan diimplementasikan kepada s iswa dikelas, guru membuat video pembelajaran tentang alat, bahan yang digunakan dan proses dalam pembuatan karya batik jumputan, (2) Konsep dan teknik dalam proses pembuatan karya batik jumputan menjadi benda siap pakai. Karya yang dihasilkan oleh guru-guru (pes erta) berupa alas meja lover/alas meja tamu. Jadi guru dalam mengikuti pelatihan ini
Gorga : Jurnal Seni Rupa

Volume 09 Nomor 02 Juli-Desember 2020

p-ISSN: 2301-5942 | e-ISSN: 2580-2380

memperoleh dua jenis keterampilan, yaitu keterampilan dalam membuat multimedia interaktif berupa video pembelajaran tentang batik jumputan mulai dari pengetahuan alat dan bahan sampai kepada proses pembuatan batik jumputan. Dimana video ini akan dijadikan guru sebagai media pembelajaran untuk menyampaikan materi kepada siswa dikelas. Kemudian guru mendapatkan keterampilan dalam pembuatan karya dengan menggunakan teknik batik jumputan. Selama kegiatan penyajian materi, peserta terlihat antusias mengikuti kegiatan. Mencatat materi penting yang disajikan, aktif melakukan tanya jawab, tidak keluar ruangan kalau tidak terlalu penting.

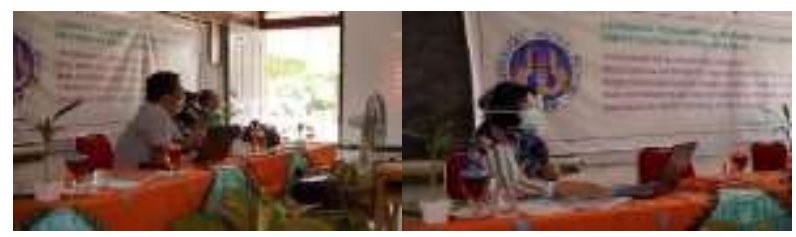

Gambar 1. Penyampaian Mater kepada Peserta (Ahdi, 2020)
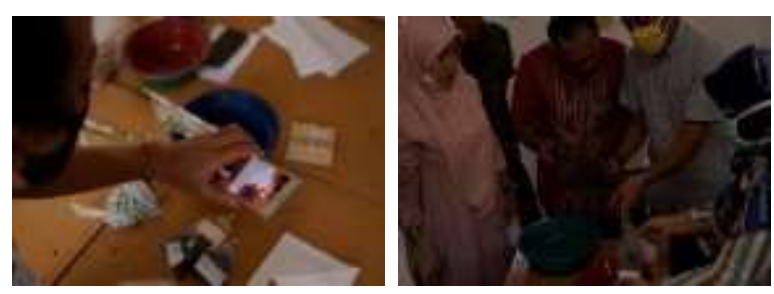

Gambar 2. Proses Kerja Peserta (Ahdi, 2020)

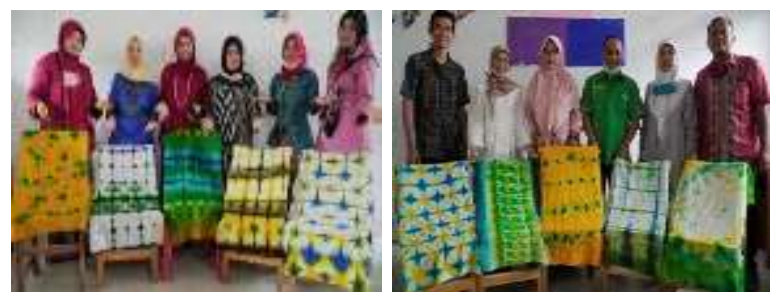

Gambar 3. Hasil Karya dari Peserta (Ahdi, 2020)

\section{Pembahas an}

Target luaran kegiatan yang ditetapkan dalamkegiatan multimedia interaktif materi teknik batik jumputan demi pengembangan pembelajaran seni budaya dan keterampilan ini adalah peserta menghasilkan multimedia interaktif berupa video pembelajaran tentang materi batik jumputan mulai dari pengetahuan alat dan bahan serta proses membatik tersebut. Peserta mampu menghasilkan video pembelajaran mulai dari proses pengambilan gambar kegiatan sampai kepada proses editing sehingga menghasilkan sebuah video yang dapat digunakan oleh guru untuk menjelaskan materi batik jumputan ini ke siswa dikelas nantinya. Artinya, setiap peserta dalam pelatihan tersebut memiliki keterampilan dan pengetahuan didalam 
pembuatan video pembelajaran. Tidak hanya itu guru dalam mempermudah menjelaskan materi batik jumputan ini ke siswa, dengan demikian maka target luaran yang ditetapkan sudah dapat dicapai dengan baik. Pembahasan disesuaikan dengan dua aspek permasalahan dan target luaran pada setiao aspek permasalahan.

\section{KESIMPULAN DAN SARAN 1.Kesimpulan}

Penguasaan materi pembelajaran Seni Budaya dan Keterampilan. Guru SDN Mitra telah dapat memahami pengetahuan tentang membatik jumputan: pengertian batik, alat dan bahan, teknik membatik, proses pembuatan batik pada pembelajaran seni budaya dan keterampilan. Sesuai dengan target luaran: (1) telah dihasilkan produk berupa jobshet atau media pembelajaran mengenai pengetahuan batik jumputan dan (2) telah terjadi peningkatan pemahaman guru SDN mitra sekitar $80 \%$ dalam menguasai materi pelatihan membatik jumputan.

Guru SDN Mitra telah dapat memahami pengertian dan konsep membatik dalam pembuatan karya yang memiliki fungsi pakai dan fungsi hias (fine art) pada pembelajaran Seni Budaya dan Keterampilan. Dalam pembuatan karya dengan menggunakan teknik batik jumputan ini akan menghasilkan berbagai macam produk yang dihasilkan, baik itu karya dua dimensi ataupun karya tiga dimensi. Karya yang bis a dipajang maupun karya yang bisa dipakai untuk memenuhi kebutuhan sehari-hari, misalnya bisa dijadikan baju, house ware, alas meja, alas s arung bantal kursi dan lain sebagainya. Sehingga telah terjadi peningkatan pemahaman guru-guru SDN mitra setelah mendengarkan materi yang diberikan dan dengan berbagai model karya yang diperlihatkan sebagai contoh karya. Sesuai dengan target luaran: (1) telah dihasilkan tiga buah model karya batikjumputan yang memiliki fungsi pakai dan fungsi hias sebagai media yang digunakan pada saat pelatihan (2) sekitar $80 \%$ materi pelatihan dikuasai oleh peserta, sehingga telah terjadi peningkatan terhadap pemahaman guru SDN mitra tentang konsep membatik dalam pembuatan karya yang memiliki fungsi pakai dan fungsi hias (fine art).

Penguasaan dan penerapan materi pembelajaran seni budaya dan keterampilan dengan target luaran berupa: Peningkatan pemahaman oleh Guru SDNMitra dengan s pesifikasi minimal $80 \%$ materipelatihan dikuasai oleh Guru SDN Mitra. Target luaran kegiatan ini sudah dapat dicapai. Hasil pengukuran kemampuan awal, hanya sebanyak $40 \%$ materi pengertian, konsep, bahan,
Gorga : Jurnal Seni Rupa

Volume 09 Nomor 02 Juli-Desember 2020 p-ISSN: 2301-5942 | e-ISSN: 2580-2380

dan proses pembuatan karya seni rupa dan keterampilan dengan mempergunakan teknik batik jumputan sebagai pembuatan karya praktikum yang dikuasai oleh Guru SDN Mitra. Rendahnya kemampuan peserta pelatihan ini disebabkan mereka baru mengenal cara mengolah dan membuat suatu karya yang bernilai seni dengan menggunakan teknik batik jumputan ini. Selama ini guru SDN Mitra belum bis a menerapkan Teknik dan proses membatik jumputan ke dalam bentuk tugas tang akan dikerjakan siswa yang dijadikan sebagai bahan praktikum pada pembelajaran seni budaya dan prakarya. Pada akhir kegiatan, sebanyak $80 \%$ materi pengertian, konsep, bahan, dan proses pembuatan karya seni rupa dan prakarya dengan mempergunakan teknik batik jumputan sebagai bahan pembuatan karya praktikum sudah dikuasai oleh Guru SDN Mitra. Tingkat persentese ini sudah melebihi target penguasaan yang ditetapkan sebanyak $80 \%$.

Produk berupa beberapa karya dengan menggunakan teknik batik jumputan yang bisa dijadikan sebagai karya siap pakai. Hasil yang didapatkan adalah peserta mampu mengaplikasikan atau membuat karya seni yang memiliki fungsi pakai dengan menggunakan Teknik batik jumputan.

Minimal peserta menghasilkan suatu karya keterampilan dengan menggunakan teknik batik jumputan. Peserta telah menghasilkan karya keterampilan dari Teknik batikjumputan sesuai dengan target luaran yang ditetapkan, Karya-karya yang dibuat oleh peserta tersebut telah dipamerkan dari tanggal 8 sampai dengan 9 Oktober 2020 di salah satu ruangan kelas SDN 53 Kampung Jambak Padang. Pembuatan multimedia interaktif presentasi materi pembelajaran seni budaya dan keterampilan.

Peningkatan pemahaman guru SDN mitra dalam menguasai materi multimedia interaktif dalam pembuatan video pembelajaran materi batik jumputan sekitar $80 \%$ materi pelatihan dikuasai. Sehingga diakhir pelatihan guru-guru mampu menghasilkan produk berupa multimedia interaktif presentasi materi batik jumputan yang bis a dijadikan media bagi guru untuk menjelaskan materi ke siswa, dimana tampilan presentasinya menggunakan tampilan visual yang bagus dan ditambahi deng an videonya, sehingga siswa akan lebih tertarik untuk mempelajari dan men gerjakan prakarya yang ditugaskan oleh guru. Jadi dalam pelatihan tersebut 1 orang guru dari masing-masing mitra menyelesaikan video interaktifnya, mulai dari pengetahuan alat dan bahan sampai kepada proses pembuatan batik jumputan. Dan proses editing video 


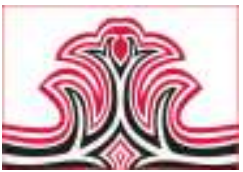

juga sudah dikuasai oleh guru tersebut sehingga guru tersebut menghasilkan 1 buah video yang bisa dijadikan guru untuk menjelaskan materi batik jumputan tersebut ke siswa nantinya dikelas.

\section{Saran}

Semoga dengan adanya pelatihan ini bis a bermanfaat kepada kedua mitra, SDN 50 dan SDN 53 Kampung Jambak Padang. Apa yang sudah didapatkan dari pelatihan bis a dikembangkan oleh peserta, baik ilmu tentang teknik batikjumputan dan pengetahuan tentang multimedia interaktif presentasi materi pembelajaran senibudaya dan keterampilan khususnya tentang batik jumputan.

\section{DAFTAR RUJUKAN}

Ahdi, S. (2020). "Dokumentasi Hasil Karya Peserta Pengabdian". Hasil Dokumentasi Pribadi: 20 Agustus 2020, SDN 50 dan 53 Kampung Jambak Padang.

Astuti, Midiah. (2014). Batik Ikat Celup Permata bunda (Parang Kaliurang)

Hargobinangun. Sleman: Skripsi UNY.

Maleong, L. J. (2005). Metodologi Penelitian Kualitatif. Bandung: PT. Remaja Rosda Karya.

Wardoyo, S., \& Widodo, S. T. (2018). Kreasi Motif pada Produk Tie-Dye (Ikat Celup) di Kota Yogyakarta. Yogyakarta: Badan Penerbit Institut Seni Indonesia Yogyakarta. 